\title{
Metronidazole-induced fixed drug eruption
}

\author{
Naveen Kumar, ${ }^{1}$ Deepak Sundriyal, ${ }^{2}$ Meenu Walia, ${ }^{2}$ Deepshikha Trisal ${ }^{1}$
}

1 Department of Internal Medicine, PGIMER \& Dr Ram Manohar Lohia Hospital, New Delhi, India ${ }^{2}$ Department of Medical Oncology, Dharamshila Hospital, New Delhi, India

\section{Correspondence to}

Dr Naveen Kumar,

docnaveen2605@yahoo.co.in

\section{(a) CrossMark}

To cite: Kumar $\mathrm{N}$ Sundriyal $D$, Walia $M$, et al. BMJ Case Rep Published online: [please include Day Month Year] doi:10.1136/ bcr-2013-200470

\section{DESCRIPTION}

A 67-year-old man presented with a history of an itchy, erythematous oval lesion over the right calf (figure 1). He was prescribed metronidazole for dysentery 1 day earlier. He mentioned history of a similar eruptive lesion in the same location, after he was prescribed metronidazole for an episode of diarrhoea about 4 months previously. At that time, the lesion appeared after 3 days of treatment. It was itchy and it healed after stopping the drug leaving a residual hyperpigmentation. Hence, we suspected it to be fixed drug eruption (FDE) due to metronidazole. As oral challenge test is risky and patch test is not available in our clinic, we assessed a causal relation between the drug and the adverse drug reaction (ADR) using Naranjo et al's ${ }^{1}$ algorithm. The patient presented with drug eruption immediately after oral administration of metronidazole $(+2)$ and rapidly recovered after stopping the drug $(+1)$. There was a history of similar episode to the same drug 4 months previously $(+1)$. There was no alternative explanation for the reaction $(+2)$. Moreover, cases of FDE due to metronidazole have been reported previously $(+1)^{2}$ According to the Naranjo ADR probability scale (score $=7$ ), we categorised it as a 'probable' reaction to the drug. In severity assessment it was a mild ADR (level 2) as per Hartwig $e t a l^{3}$ scale. We kept arthropod bite reaction and erythema multiforme as possible differentials. However, there was no history of insect bite. The lesions were not target shaped, which are typical of erythema multiforme; moreover, typical temporal association with drug and the fixed location also goes against it. Common causes of FDE are antibiotics (sulfonamides, tetracycline) and non-steroidal antiinflammatory drugs. ${ }^{2}$ The hallmark of this reaction is the occurrence of eruptions in the same location during each episode. The lesions usually occur on the lips, face, hands, feet and genitalia. They are dusky erythematous macule, often associated with a

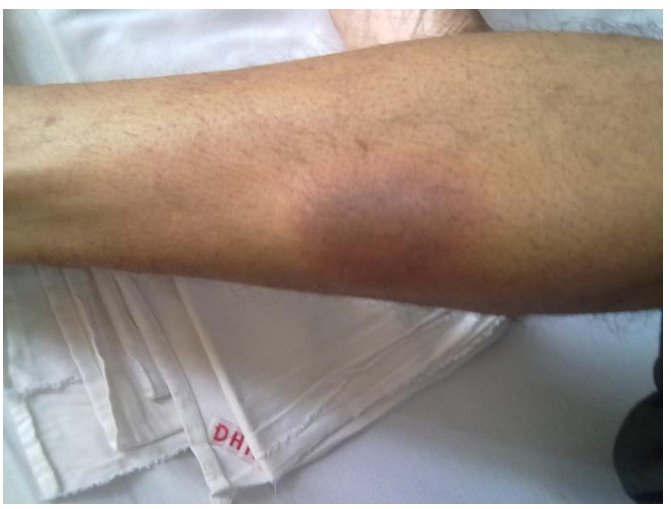

Figure 1 Well-defined erythematous macule over the right calf. burning sensation and may present in multiple numbers. They can progress to the development of central vesicles and bullae, particularly after repeated use. Persistent hyperpigmentation at the site of the lesion can be seen after healing. Drugs with a similar structure can cause cross sensitivity. The offending drug is thought to function as a hapten that preferentially binds to basal keratinocytes, thereby releasing lymphokines and antibodies thus damaging the basal cell layer. If the patient is rechallenged with the offending drug, the eruption occurs repeatedly at the identical skin site (ie, fixed). The diagnosis of FDE is usually evident from the history and clinical examination. However, it can be confirmed using oral challenge test and patch test. The former can be risky as it can lead to reactivation with increased severity and anaphylactic reaction. Patch test has many advantages: it is safe, several drugs can be studied at the same time, and can study cross reaction between drugs also. The patient was advised not to take metronidazole in the future.

\section{Learning points}

- Importance of fixed drug eruption lies in the fact that they are caused by commonly used drugs. Antibiotics followed by non-steroidal anti-inflammatory drugs are most common culprits.

- If the drug is not avoided, recurrent episodes can be more severe and extensive with residual postinflammatory hyperpigmentation.

- Diagnosis is based on fixed location of skin lesion and following intake of drug of the same group.

Contributors DS and NK participated in patient management conception, data acquisition, article drafting, revision and final approval. MW participated in patient management, conception, revision and final approval. DT participated in patient management, data acquisition, article drafting and final approval.

\section{Competing interests None.}

Patient consent Obtained.

Provenance and peer review Not commissioned; externally peer reviewed.

\section{REFERENCES}

1 Naranjo CA, Busto U, Sellers EM, et al. A method for estimating the probability of adverse drug reactions. Clin Pharmacol Ther 1991;30:239-45.

2 Wahlang JB, Sangma KA, Marak MD, et al. Fixed drug eruption due to metronidazole: review of literature and a case report. Int Pharma Sci Res (IJPSR) 2012;3:331-4.

3 Hartwig SC, Siegel J, Schneider PJ. Preventability and severity assessment in reporting adverse drug reactions. Am J Hosp Pharm 1992:49:2229-32. 
Copyright 2013 BMJ Publishing Group. All rights reserved. For permission to reuse any of this content visit http://group.bmj.com/group/rights-licensing/permissions.

BMJ Case Report Fellows may re-use this article for personal use and teaching without any further permission.

Become a Fellow of BMJ Case Reports today and you can:

- Submit as many cases as you like

- Enjoy fast sympathetic peer review and rapid publication of accepted articles

- Access all the published articles

- Re-use any of the published material for personal use and teaching without further permission

For information on Institutional Fellowships contact consortiasales@bmjgroup.com

Visit casereports.bmj.com for more articles like this and to become a Fellow 